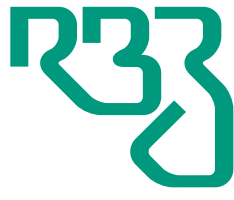

Revista Brasileira de Zootecnia

Brazilian Journal of Animal Science ISSN 1806-9290 www.rbz.org.br

\title{
Energetic metabolism in fasting sheep: regularization of metabolic profile by treatment with oral glucose, with prior handling of gastric groove
}

\author{
María José Martín-Alonso $^{1,2}$ iD, Francisco Escalera-Valente ${ }^{3}$ iD, Luis G. \\ Cal-Pereyra $^{4}$ iD , Alejandro Benech ${ }^{5}$, María Pilar Alonso ${ }^{1}$, José Ramiro \\ González-Montaña ${ }^{1 *}$ iD \\ ${ }^{1}$ University of León, Veterinary Faculty, Medicine, Surgery and Anatomy Veterinary \\ Department, León, Spain. \\ ${ }^{2}$ University of Lleida, Department of Animal Science, Lleida, Spain. \\ ${ }^{3}$ Autonomous University of Nayarit, Academic Unit of Veterinary Medicine, Tepic, \\ Nayarit, Mexico. \\ ${ }^{4}$ University of La República, Veterinary Faculty, Pathology Department, Montevideo, \\ Uruguay. \\ ${ }^{5}$ University of La República, Veterinary Faculty, Small Animals Department, Montevideo, \\ Uruguay.
}

\author{
*Corresponding author: \\ jramirogonzalez@unileon.es \\ Received: January 14, 2019 \\ Accepted: August 25, 2019 \\ How to cite: Martín-Alonso, M. J.; Escalera- \\ Valente, F.; Cal-Pereyra, L. G.; Benech, A.; \\ Alonso, M. P. and González-Montaña, J. R. \\ 2019. Energetic metabolism in fasting sheep: \\ regularization of metabolic profile by treatment \\ with oral glucose, with prior handling of \\ gastric groove. Revista Brasileira de Zootecnia \\ 48:e20180290. \\ https://doi.org/10.1590/rbz4820180290 \\ Copyright: This is an open access article \\ distributed under the terms of the \\ Creative Commons Attribution License \\ (http://creativecommons.org/licenses/by/4.0/), \\ which permits unrestricted use, distribution, \\ and reproduction in any medium, provided the \\ original work is properly cited.
}

\begin{abstract}
The objective of this research was to evaluate a possible corrective measure against negative metabolic states, as occurs in the advanced stage of gestation in ewes, and that sometimes produces a disease called pregnancy toxaemia. In the present research, we found that the joint administration of i.v. lysine-vasopressin ( $0.08 \mathrm{IU} / \mathrm{kg}$ body weight, BW) and an oral glucose solution ( $50 \mathrm{~g}$ ) produces an increase in blood glucose, which persists for some time (up to $6 \mathrm{~h}$ ); therefore, it could be used in the treatment of pregnancy toxaemia. This therapy is based on the fact that lysine-vasopressin induces gastric groove closure in adult ruminants, enabling orally administered glucose to reach the abomasum directly, from where it rapidly passes into the intestine and is immediately absorbed. We can say that the tested treatment causes a significant increase in blood glucose in ewes affected by toxaemia caused by fasting, which, although less marked than conventional therapy with intravenous drip glucose, remains longer, regularizing other parameters indicative of energy metabolism in fasting ewes.
\end{abstract}

Keywords: ewes, gastric groove, glycaemia, metabolism, pregnancy, toxaemia, vasopressin

\section{Introduction}

Among the diseases that affect energy metabolism in sheep, ovine pregnancy toxaemia (OPT) stands out. It is a metabolic disorder that affects ewes mainly with multiple gestations due to an imbalance between energy intake and increased needs in the final phase of pregnancy, since during the last six weeks of gestation, there is between 75 and $80 \%$ of foetal growth (Sargison, 2007).

Therefore, ewes in their last third of pregnancy have energy and protein requirements 1.5 to 2.0 times higher than when they are at the start of gestation (Andrews, 1997). Besides, in late gestation, fat and an ever-expanding uterus, as a result of foetal growth, can fill the abdominal cavity. Therefore, due to the lack of rumen space, these ewes have difficulty consuming enough feedstuff to satisfy their energy requirements (Albay et al., 2014, Lima et al., 2016), causing a decrease of $30 \%$ feed intake during the week prior to calving (Hippen et al., 2008; Lima et al., 2016). Trying to compensate this negative energy balance, ewes mobilize their body reserves of fat and proteins with consequent hepatic ketogenesis 
(Cal-Pereyra et al., 2012; Dzadzovski et al., 2015). This evolves towards serious symptoms (Rook, 2000; Sargison, 2007; Al-Mujalli, 2008; Cal-Pereyra et al., 2012; Jyothi et al., 2014), which culminate in the death of a very high number of ewes, especially untreated ones (Rook, 2000; Radostits et al., 2006; Sargison, 2007; Cal-Pereyra et al., 2012).

Both therapy and prophylaxis should be directed towards glucose formation and its use at tissue level (El-Hamamsy et al., 1990; Andrews et al., 1997; Rook, 2000; Radostits et al., 2006; Sargison, 2007; Cal-Pereyra et al., 2015b), favouring the consumption of ketone bodies (Bonino et al., 1987; Radostits et al., 2006; Sargison, 2007). Traditionally, oral administration of glucose has been discouraged, since it is transformed into butyric acid when reaching the rumen, with an important ketogenic effect (Cal-Pereyra et al., 2012).

On the other hand, it has been proven that intravenously administered LVP in ewes is capable of efficiently stimulating the gastric groove without marked adverse effects (El-Hamamsy et al., 1990; González-Montaña et al., 2014). This has led us to consider the possibility of jointly administering LVP and glucose orally, so that it quickly reaches the abomasum, without being fermented in the rumen. All of this would facilitate rapid absorption of glucose, increasing glycaemia in tested ewes, and could be considered an interesting strategy to increase blood glucose in sheep affected by a negative energy balance.

For this reason, we have studied the evolution of glycaemia and other indicators of ovine energy metabolism in fasting sheep, therefore with negative energy balance, after the joint administration of i.v. lysine-vasopressin and an oral glucose solution. The end objective was to test this therapeutic protocol in ewes affected by pregnancy toxaemia as an alternative to conventional therapy with intravenous glucose, since, if the glycaemia is regularized for a reasonable time, it could be used in the management of this disease.

\section{Material and Methods}

We selected 10 healthy 4-6-year-old, non-pregnant, non-lactating Assaf ewes, with a body condition score between 3.0 and 3.5 according to the Russel scale (Russel, 1984), housed on an experimental farm in León, Spain $\left(42^{\circ} 36^{\prime} 0.1^{\prime \prime} \mathrm{N}, 5^{\circ} 34^{\prime} 13.2^{\prime \prime} \mathrm{W}\right)$. All experimental procedures were carried out in compliance with the provisions of the Directive regulating the use of animals for scientific purposes in the European Union (European Union, 2010) and the Decree regulating experimentation, teaching, and animal protection in Spain (BOE, 2013), and upon approval of the local Animal Welfare Committee Subcomité para la Experimentación y Bienestar animal (OEBA- ULE) and the Dirección General de Producción Agropecuaria en Infraestructuras Agrarias de la Junta de Castilla y León, case number OEBA-ULE-013-2016.

Ewes were overfed with concentrates and forage during the previous month to cause slight fattening. Feed was composed of concentrate and forage $(0.40 \mathrm{~kg} /$ day barley and $45 \%$ soy meal, $0.15 \mathrm{~kg} / \mathrm{day}$, with free access to good quality hay, about $1.5 \mathrm{~kg} /$ day), resulting in a final ration of $92 \%$ dry matter (DM), $14.0 \%$ crude protein (CP), and $2.65 \mathrm{Mcal} / \mathrm{kg}$ DM. Later, they were subjected to a fasting period $(72-120 \mathrm{~h})$ to achieve a negative energy balance, which we verified with the appearance of ketonuria using semiquantitative test strips. Fasting was maintained throughout the experimental design. Water supply was maintained ad libitum. Once the test was finished, the sheep were fed again with the above ration.

The experiment was carried out comparing two groups, one $(\mathrm{n}=6)$ treated at $08.00 \mathrm{~h}$ with i.v. LVP ([Lys8] -Vasopressin Sigma, $250 \mathrm{IU} / \mathrm{mg}$ ) at a dose of $0.08 \mathrm{IU} / \mathrm{kg}$ BW followed by $50 \mathrm{~g}$ of glucose (C6 H12 06, D (+) - Glucose GPR Rectapur, VWR International Eurolab, 180.16 g/mol) dissolved in $1000 \mathrm{~mL}$ of water, orally administered through a nasogastric tube (to prevent the liquid from coming in contact with and stimulating receptors in the mouth and pharynx). The other group $(n=4)$ was given a standard treatment of $50 \mathrm{~mL}$ i.v. $50 \%$ sterile commercial glucose solution (glucose $50 \%$, B. Braun, glucose $50 \%$, glucose $500 \mathrm{mg} / \mathrm{mL}$, equivalent to $550 \mathrm{mg} / \mathrm{mL}$ of anhydrous glucose, with an 
energy value of $2000 \mathrm{kcal} / \mathrm{L}$ ). This group also received LVP at the aforementioned dose to eliminate the possible variables attributable to its application. The treatment was administered every $12 \mathrm{~h}$ for four days (Table 1).

Blood samples were taken from the jugular vein, always prior to the administration of each treatment tested and 15 min post-administration. To check the evolution of treatment after finishing the test, a sample was taken $12 \mathrm{~h}$ after the last application. In the first experimental cycle, animals were also sampled at 30 and $60 \mathrm{~min}$, and after 2, 4, 8, and $12 \mathrm{~h}$. This last sampling coincided with the next LVP administration, carried out $12 \mathrm{~h}$ after the first application (Table 1). Urine samples were collected at the beginning of the protocol and before each therapeutic trial, following the transient apnoea method (Benech et al., 2015).

Blood samples, except a fraction for assessment of non-esterified fatty acids (NEFA), which must be performed in whole blood, were centrifuged and the plasma frozen at $-20^{\circ} \mathrm{C}$ until they were analysed in the Laboratorio de Técnicas Instrumentales (L.T.I.) of the University of León.

Non-esterified fatty acids were quantified in whole blood, while other biochemical variables measured in plasma were glucose, $\beta$-hydroxybutyrate $(\beta \mathrm{OHB})$, aspartate aminotransferase (AST), alanine aminotransferase (ALT), alkaline phosphatase (ALP), gamma glutamyltransferase (GGT), creatinine, and calcium. Most parameters were evaluated using a Cobas Integra 400 multi-analyte analyser (Roche Diagnostics, Mannheim, Germany), by means of Roche Diagnostic reagents (Roche Diagnostics GmbH, Germany), except $\beta O H B$ and NEFA, which were measured using reagents from Randox Laboratories (Crumlin, Co., Antrim, UK). Urine samples were analyzed immediately by kit strips (Multistix 10 Visual, Bayer, USA), evaluating $\mathrm{pH}$, glucose, urine density and ketone bodies.

Data were analysed using the statistical software SPSS 20.0 (IBM, Armonk, NY). We studied both the evolution of samples during the first $12 \mathrm{~h}$ and throughout the four days of the experiment. For this, we carried out a descriptive analysis and a repeated-measures ANOVA to analyse the effects of the treatments over time (intragroup effect), whereas a Student's t test was used for intra-group analysis (between treatments). Results are expressed as mean \pm SEM, and P-value was considered statistically significant when $\mathrm{P}<0.05$.

Table 1 - Experimental design, treatment, and sampling times

\begin{tabular}{|c|c|c|}
\hline & $\begin{array}{l}\text { Treated group } \\
\qquad(\mathrm{n}=6)\end{array}$ & Standard treatment group $(n=4)$ \\
\hline $\begin{array}{l}\text { Premedication } \\
\text { (every } 12 \mathrm{~h}, 4 \mathrm{~d} \text {, } \\
\text { eight applications) }\end{array}$ & LVP 0.08 IU/kg BW, i.v. & LVP 0.08 IU/kg BW, iv. \\
\hline $\begin{array}{l}\text { Treatment } \\
\text { (every } 12 \mathrm{~h}, 4 \mathrm{~d} \text {, } \\
\text { eight applications) }\end{array}$ & $50 \mathrm{~g}$ of glucose dissolved in $1 \mathrm{~L}$ of water, per os & $50 \%$ glucose solution, $50 \mathrm{~mL}$, i.v. \\
\hline Sampling in $12 \mathrm{~h}$ & $0 \mathrm{~h}, 15 \mathrm{~min}, 30 \mathrm{~min}, 1 \mathrm{~h}, 2 \mathrm{~h}, 4 \mathrm{~h}, 8 \mathrm{~h}, 12 \mathrm{~h}(=0 \mathrm{~h})$ & $0 \mathrm{~h}, 15 \mathrm{~min}, 30 \mathrm{~min}, 1 \mathrm{~h}, 2 \mathrm{~h}, 4 \mathrm{~h}, 8 \mathrm{~h}, 12 \mathrm{~h}(=0 \mathrm{~h})$ \\
\hline Sampling in four days & $\begin{array}{c}0 \mathrm{~h},+15 \mathrm{~min} \\
12 \mathrm{~h},+15 \mathrm{~min} \\
24 \mathrm{~h},+15 \mathrm{~min} \\
36 \mathrm{~h},+15 \mathrm{~min} \\
48 \mathrm{~h},+15 \mathrm{~min} \\
60 \mathrm{~h},+15 \mathrm{~min} \\
72 \mathrm{~h},+15 \mathrm{~min} \\
84 \mathrm{~h},+15 \mathrm{~min} \\
96 \mathrm{~h}\end{array}$ & $\begin{array}{c}0 \mathrm{~h},+15 \mathrm{~min} \\
12 \mathrm{~h},+15 \mathrm{~min} \\
24 \mathrm{~h},+15 \mathrm{~min} \\
36 \mathrm{~h},+15 \mathrm{~min} \\
48 \mathrm{~h},+15 \mathrm{~min} \\
60 \mathrm{~h},+15 \mathrm{~min} \\
72 \mathrm{~h},+15 \mathrm{~min} \\
84 \mathrm{~h},+15 \mathrm{~min} \\
96 \mathrm{~h}\end{array}$ \\
\hline
\end{tabular}

\section{Results}

Some ewes, and generally in the first application of LVP, showed slight adverse reactions such as vocalization, restlessness, tremors, and mild tachypnea. These symptoms were milder or even disappeared in subsequent administrations. 
Although all sheep showed ketonuria at the beginning of the trial, always measured through semiquantitative test strips, only two of them had higher semiquantitative values, which corresponded to those females with higher values of $\beta \mathrm{OHB}$ in blood. After the first treatment, no ketonuria was detected again in any ewe.

After the administration of i.v. LVP, followed by oral glucose, a significant increase in blood glucose was observed, which rose from initial values between 1.48 and $3.87 \mathrm{mmol} / \mathrm{L}$ to between 4.41 and $10.41 \mathrm{mmol} / \mathrm{L}$ at $15 \mathrm{~min}$ post-administration. If we consider the mean values, we can observe that the initial values of $2.86 \mathrm{mmol} / \mathrm{L}$ increased to $6.43 \mathrm{mmol} / \mathrm{L}$ after $15 \mathrm{~min}$, the highest values being found $1 \mathrm{~h}$ after the tested therapy (7.64 mmol/L) (Table 2; Figure 1). Subsequently, blood glucose decreased continuously, reaching minimum values in the moments prior to the application of the following treatment (Table 2; Figure 1). Although with higher glycaemia in the whole experiment, the increase was no longer significant $4 \mathrm{~h}$ after treatment. A lower increase in blood glucose was also observed in those sheep with lower glycaemia at the beginning of the experiment.

Table 2 - Values of glucose, $\beta$ OHB, NEFA, and calcium (in mmol/L) in two treatments and in different sampling times, corresponding to $12 \mathrm{~h}$ after the administration of the treatment

\begin{tabular}{|c|c|c|c|c|c|c|c|c|}
\hline \multirow[b]{2}{*}{ Sampling } & \multicolumn{2}{|c|}{ Glucose } & \multicolumn{2}{|c|}{$\beta \mathrm{OHB}$} & \multicolumn{2}{|c|}{ NEFA } & \multicolumn{2}{|c|}{ Calcium } \\
\hline & $\begin{array}{l}\mathrm{LVP}+\text { Glc oral } \\
\quad(\mathrm{n}=6)\end{array}$ & $\begin{array}{l}\text { LVP + Glc i.v. } \\
\quad(\mathrm{n}=4)\end{array}$ & $\begin{array}{l}\mathrm{LVP}+\text { Glc oral } \\
\quad(\mathrm{n}=6)\end{array}$ & $\begin{array}{l}\text { LVP + Glc i.v. } \\
\quad(\mathrm{n}=4)\end{array}$ & $\begin{array}{c}\mathrm{LVP}+\text { Glc oral } \\
\quad(\mathrm{n}=6)\end{array}$ & $\begin{array}{l}\text { LVP + Glc i.v. } \\
\quad(\mathrm{n}=4)\end{array}$ & $\begin{array}{c}\mathrm{LVP}+\text { Glc oral } \\
\quad(\mathrm{n}=6)\end{array}$ & $\begin{array}{l}\text { LVP + Glc i.v. } \\
\quad(n=4)\end{array}$ \\
\hline $0 \mathrm{~h}$ & $2.86 \pm 0.97 \mathrm{a}, \mathrm{e}, *$ & $2.71 \pm 0.25 \mathrm{a}, \mathrm{e}, *$ & $0.73 \pm 0.23 a$ & $0.75 \pm 0.12 \mathrm{a}, \mathrm{d}$ & $0.77 \pm 0.29$ & $0.79 \pm 0.14 \mathrm{a}, \mathrm{c}$ & $2.52 \pm 0.20$ & $2.41 \pm 0.11 \mathrm{a}, \mathrm{b}$ \\
\hline $15 \mathrm{~min}$ & $6.43 \pm 1.78 \mathrm{~b}, \mathrm{c}, \mathrm{d}, *$ & $20.76 \pm 1.93 b, *$ & $0.55 \pm 0.14 \mathrm{~b}, \mathrm{~d}$ & $0.50 \pm 0.07 a, c$ & $0.58 \pm 0.16 \mathrm{a}$ & $0.61 \pm 0.08 \mathrm{~b}, \mathrm{c}$ & $2.47 \pm 0.19$ & $2.33 \pm 0.19 \mathrm{a}, \mathrm{b}$ \\
\hline $30 \mathrm{~min}$ & $7.18 \pm 1.54 b, c, *$ & $16.57 \pm 2.45 c^{*}$, & $0.36 \pm 0.14 \mathrm{c}$ & $0.25 \pm 0.05 b, c$ & $0.33 \pm 0.14 \mathrm{~b}$ & $0.50 \pm 0.17$ & $2.46 \pm 0.15 \mathrm{a}, \mathrm{b}$ & $2.41 \pm 0.10$ \\
\hline $1 \mathrm{~h}$ & $7.64 \pm 1.93 \mathrm{~b}, *$ & $12.40 \pm 3.05 \mathrm{~d}^{*}$ & $0.40 \pm 0.10 \mathrm{~b}, \mathrm{c}, *$ & $0.24 \pm 0.09 \mathrm{c}, *$ & $0.29 \pm 0.12 b$ & $0.44 \pm 0.09 \mathrm{~b}, \mathrm{c}$ & $2.50 \pm 0.18 \mathrm{a}, \mathrm{c}$ & $2.30 \pm 0.16$ \\
\hline $2 \mathrm{~h}$ & $6.92 \pm 2.16 c^{*}$ & $7.76 \pm 3.87 \mathrm{a}^{*}$ & $0.50 \pm 0.13 b, c, d, *$ & $0.32 \pm 0.11^{*}$ & $0.37 \pm 0.31$ & $0.43 \pm 0.12 b$ & $2.47 \pm 0.17 \mathrm{~b}$ & $2.30 \pm 0.11 \mathrm{a}, \mathrm{c}$ \\
\hline $4 \mathrm{~h}$ & $5.15 \pm 1.17 \mathrm{~d}, \mathrm{e}^{*}$ & $4.26 \pm 1.77 \mathrm{e}^{*}$ & $0.50 \pm 0.11$ & $0.37 \pm 0.11$ & $0.28 \pm 0.13 b$ & $0.46 \pm 0.11 b, c$ & $2.52 \pm 0.13$ & $2.32 \pm 0.10 \mathrm{a}$ \\
\hline $8 \mathrm{~h}$ & $3.43 \pm 0.64 \mathrm{e}^{*}$ & $3.45 \pm 0.49 \mathrm{a}, \mathrm{e}, *$ & $0.47 \pm 0.12$ & $0.51 \pm 0.05 \mathrm{~d}$ & $0.33 \pm 0.19^{*}$ & $0.66 \pm 0.27^{*}$ & $2.51 \pm 0.17 \mathrm{c}$ & $2.40 \pm 0.08 b, c$ \\
\hline $12 \mathrm{~h}$ & $2.98 \pm 0.90 \mathrm{a}, *$ & $3.53 \pm 0.28 \mathrm{a}, \mathrm{e}, *$ & $0.56 \pm 0.13 \mathrm{a}, \mathrm{d}$ & $0.45 \pm 0.07 \mathrm{~d}$ & $0.43 \pm 0.26$ & $0.67 \pm 0.23 \mathrm{c}$ & $2.51 \pm 0.16$ & $2.51 \pm 0.12 \mathrm{c}$ \\
\hline
\end{tabular}

LVP + Glc oral: lysine-vasopressin + oral glucose; LVP + Glc i.v.: lysine-vasopressin + commercial glucose solution i.v.

NEFA - non-esterified fatty acids; $\beta \mathrm{OHB}$ - $\beta$-hydroxybutyrate.

The values are expressed as mean \pm SEM.

Different letters per column indicate statistical difference between sampling time.

Asterisk $(*)$ indicate statistical difference between treatments. Statistical differences: $\mathrm{P}<0.05$

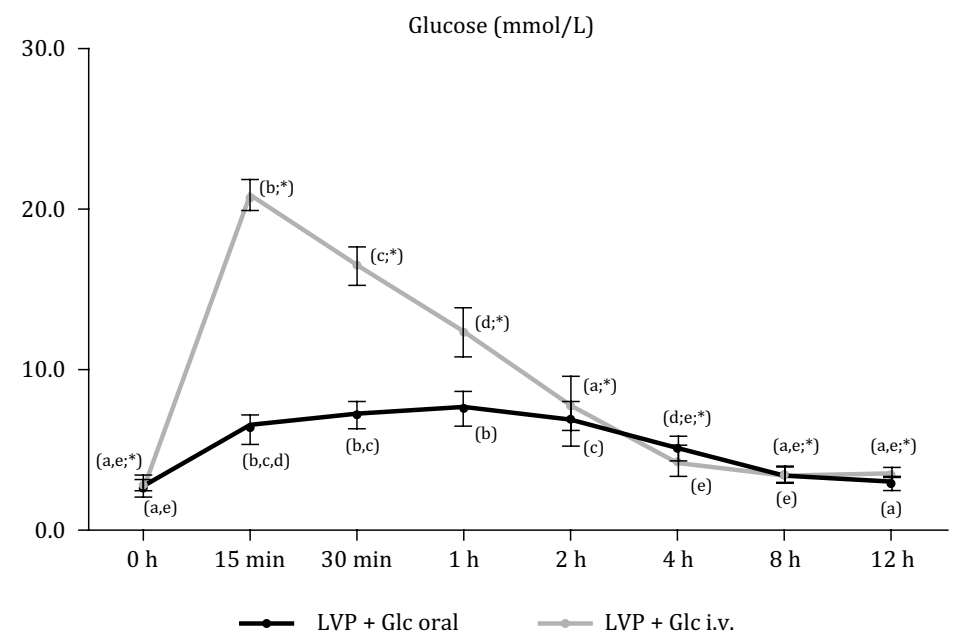

LVP + Glc oral: lysine-vasopressin + oral glucose; LVP + Glc i.v.: lysine-vasopressin + commercial glucose solution i.v. Different letters indicate statistical difference between sampling time.

Asterisk $(*)$ indicate statistical difference between treatments $(\mathrm{P}<0.05)$

Figure 1 - Evolution of glycaemia at different sampling times, corresponding to $12 \mathrm{~h}$ after the administration of treatment. 
The evolution of glycaemia observed throughout the experiment was similar to that described above (Table 3; Figure 2), always increasing quite evidently and later decreasing. We even observed that glycaemia levels in some animals dropped to minimum values $96 \mathrm{~h}$ after the start of the experiment, even to below those found at the beginning of the experiment.

Ewes administered i.v. glucosaline fluid presented initial blood glucose values between 2.44 and $2.98 \mathrm{mmol} / \mathrm{L}$, rising rapidly to 17.60 and $22.29 \mathrm{mmol} / \mathrm{L}$ after $15 \mathrm{~min}$ post-administration, their mean values increasing from 2.71 to $20.76 \mathrm{mmol} / \mathrm{L}$ (Table 2; Figure 1). In the hours following, blood glucose fell steadily, which became apparent 30 min after treatment, was no longer significant after two hours, and reached values close to initial ones by the end of the experiment. Something similar occurred in successive applications, with a rapid and marked rise in blood glucose in all sheep after treatment. We observed that $96 \mathrm{~h}$ after the start of the trial, blood glucose dropped to values close to the initial ones, though slightly higher (Table 3; Figure 2).

The statistical study of glycaemia indicates significant differences between the two treatments tested at $15 \mathrm{~min}, 30 \mathrm{~min}$, and $1 \mathrm{~h}$ post-application (Table 2; Figure 1). When we study the evolution in the four days of the test, the statistical difference is shown at $15 \mathrm{~min}$ after all applications, but not in the last sampling, after $96 \mathrm{~h}$ (Table 3; Figure 2).

The initial amounts of $\beta O H B$ in the treated group ranged between 0.51 and $1.1 \mathrm{mmol} / \mathrm{L}$, with a mean value of $0.73 \mathrm{mmol} / \mathrm{L}$ (Table 2; Figure 3). After the first administration of oral glucose, the evolution of this ketone body was inverse to that presented by glycaemia, decreasing in all sheep and showing a mean value of $0.55 \pm 0.14 \mathrm{mmol} / \mathrm{L} 15 \mathrm{~min}$ post-administration. Although blood values of $\beta O H B$ decreased after the first treatment, the minimum value was found between 30 min and $1 \mathrm{~h}$ post-administration, with a mean value of 0.36 and $0.40 \mathrm{mmol} / \mathrm{L}$. There were statistical differences in all the samplings when

Table 3 - Glucose, $\beta O H B, N E F A$, and calcium values (in mmol/L) in two treatments and in different sampling times throughout the trial

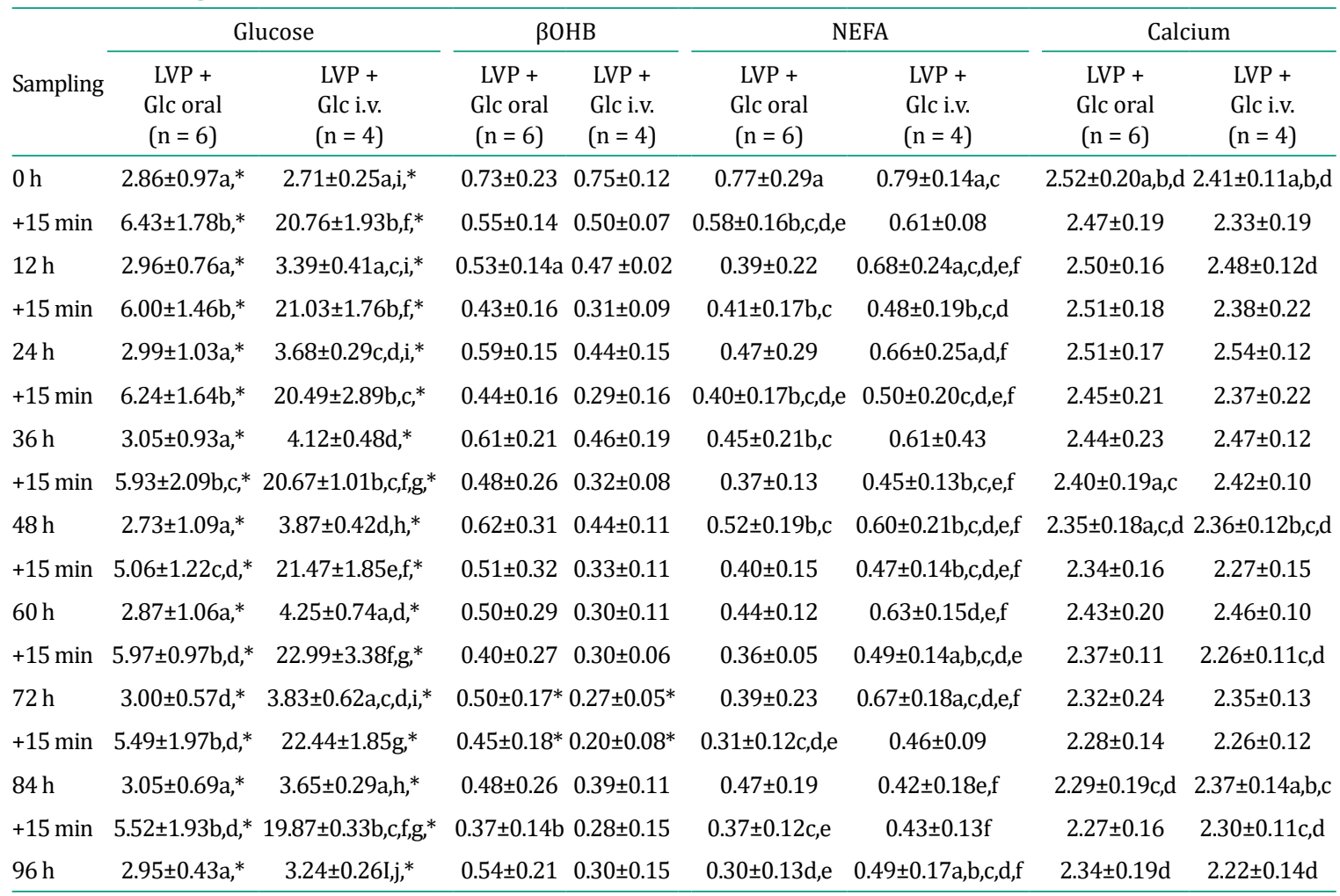

LVP + Glc oral: lysine-vasopressin + oral glucose; LVP + Glc i.v.: lysine-vasopressin + commercial glucose solution i.v.

NEFA - non-esterified fatty acids; $\beta \mathrm{OHB}$ - $\beta$-hydroxybutyrate.

The values are expressed as mean \pm SEM.

Different letters per column indicate statistical difference between sampling time.

Asterisk $\left({ }^{*}\right)$ indicate statistical difference between treatments. Statistical differences: $\mathrm{P}<0.05$. 


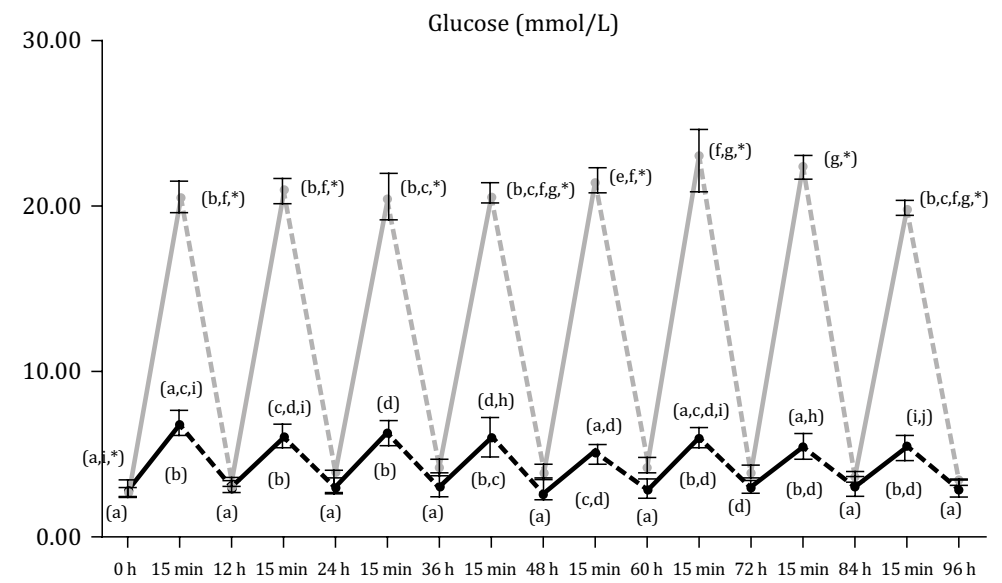

$$
\text { LVP + Glc oral } \quad \text { LVP + Glc i.v. }
$$

LVP + Glc oral: lysine-vasopressin + oral glucose; LVP + Glc i.v.: lysine-vasopressin + commercial glucose solution i.v. Different letters indicate statistical difference between sampling time. Asterisk $(*)$ indicate statistical difference between treatments $(\mathrm{P}<0.05)$

Figure 2 - Evolution of glycaemia in two treatments and at different sampling times throughout the trial.

compared with the initial value (Table 2; Figure 3). Generally, values declined after each treatment, although with an irregular evolution. At $96 \mathrm{~h}$, and except for one sheep, we observed blood $\beta O H B$ values lower than the initial ones. We only detected significant differences between both therapies in values found 1 and $2 \mathrm{~h}$ post-therapy.

In the group that received a standard treatment based on commercial glucose solution, the mean value of $\beta O H B$ pre-treatment was $0.75 \pm 0.12 \mathrm{mmol} / \mathrm{L}$. Blood values decreased after treatment, with minimum values between $30 \mathrm{~min}$ and $1 \mathrm{~h}$ post-administration $(0.25$ and $0.24 \mathrm{mmol} / \mathrm{L})$. Statistical differences appeared $30 \mathrm{~min}$ and remained throughout the experiment, always being lower than those found in the group treated with oral glucose (Table 2; Figure 3).

The evolution of $\beta O H B$ in subsequent applications was similar in all sheep, decreasing after treatment, and being lower than the initial values at 72, 84, and $96 \mathrm{~h}$ (Table 3; Figure 4).

The performance of NEFA was similar to that described for blood $\beta O H B$, decreasing at the start of the treatment, showing the highest values at 8 and $12 \mathrm{~h}$ from the start of the trial (Table 2; Figure 5). The values were always higher in the group treated with i.v. glucose than in the oral glucose group (Table 3; Figure 6). The evaluated enzymes (AST, ALT, and GGT) as well as creatinine and blood urea were similar in all sampled sheep, with hardly any variations.

We only found a small decrease in blood calcium levels in both groups at 15 min post-administration, and although the serum calcium level was always higher in the sheep treated with oral glucose, we did not find statistical differences between the groups, with a tendency to equalise at the end of the experiment (Tables 2 and 3; Figures 7 and 8).

\section{Discussion}

Initial glycaemia levels found in ewes in the trial ranged between 1.49 and $3.87 \mathrm{mmol} / \mathrm{L}$, while physiological values for sheep varied between 2.78 and $4.44 \mathrm{mmol} / \mathrm{L}$ (Andrews et al., 1997; Radostits et al., 2006; Kaneko et al., 2008). This variation may have been due to the overfeeding and subsequent feed restriction that the animals were subjected to (Andrews et al., 1997; Mahmoud and Azab, 2014). In addition, ketonemia and ketonuria were observed as a consequence of the increase in BOHB (Kaneko et al., 2008) and NEFA (Lacetera et al., 2001).

The rapid increase in glycaemia in ewes administered LVP followed by oral glucose could be attributed to the closure of the gastric groove by the action of LVP, allowing the glucosaline solution 


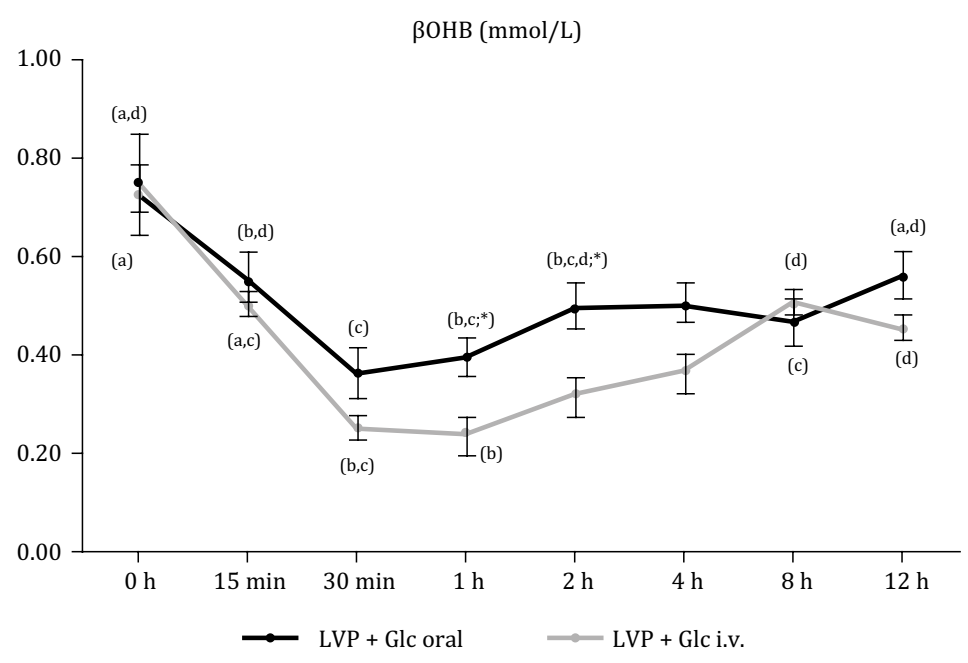

LVP + Glc oral: lysine-vasopressin + oral glucose; LVP + Glc i.v.: lysine-vasopressin + commercial glucose solution i.v. Different letters indicate statistical difference between sampling time.

Asterisk $(*)$ indicate statistical difference between treatments $(\mathrm{P}<0.05)$

Figure 3 - Evolution of serum $\beta$-hydroxybutyrate ( $\beta \mathrm{OHB})$ at different sampling times, corresponding to $12 \mathrm{~h}$ after the administration of treatment.

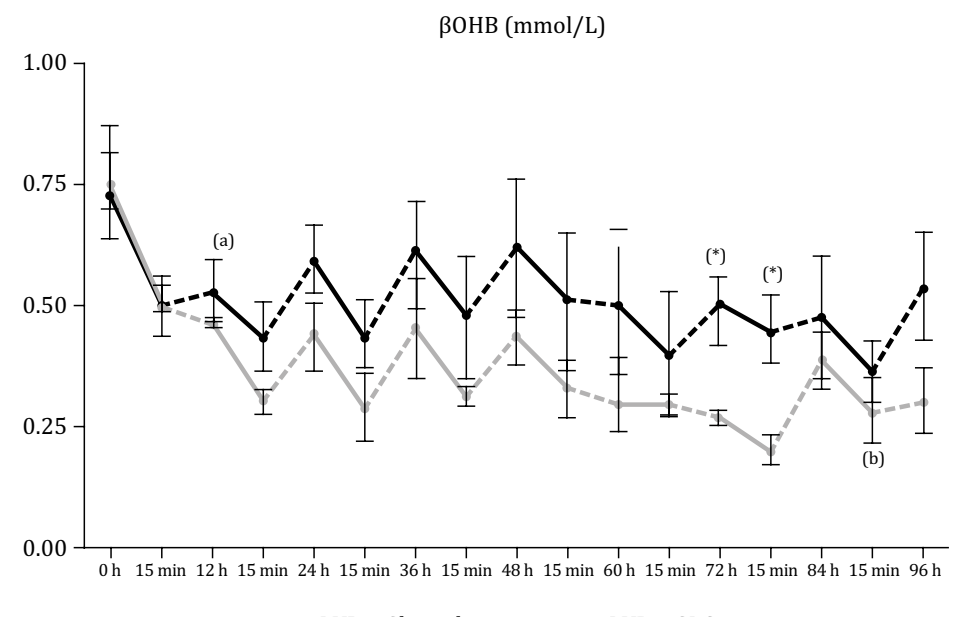

LVP + Glc oral: lysine-vasopressin + oral glucose; LVP + Glc i.v.: lysine-vasopressin + commercial glucose solution i.v. Different letters indicate statistical difference between sampling time.

Asterisk $(*)$ indicate statistical difference between treatments $(\mathrm{P}<0.05)$.

Figure 4 - Evolution of serum $\beta$-hydroxybutyrate ( $\beta O H B)$ in two treatments and at different sampling times throughout the trial.

to reach the abomasum directly and the intestine, where it was rapidly absorbed (Rehage, 1986; Scholz and Rehage, 1987; Mir and Malik, 2003; El-Hamamsy et al., 1990), causing an increase in blood glucose at $30 \mathrm{~min}$, which lasted up to $4 \mathrm{~h}$, and returned to initial levels after $8 \mathrm{~h}$ (Mikhail et al., 1988). El-Hamamsy et al. (1990) obtained increases in glycaemia from the first treatment with oral glucose after administering LVP, remaining at significant levels even after treatment had ended. In addition, Tsiamitas and Brikas (1981), using copper sulphate in sheep, managed to stimulate the gastric groove, verifying that oral administration $(100 \mathrm{~mL})$ of a $20 \%$ glucosaline solution caused a significant increase in glycaemia.

All this coincides with our results, since after the application of intravenous vasopressin and the oral glucosaline solution, we verified an important increase in glycaemia in all ewes. Thus, in most cases, the highest values were obtained $1 \mathrm{~h}$ after treatment, also coinciding with the presence of glycosuria. 


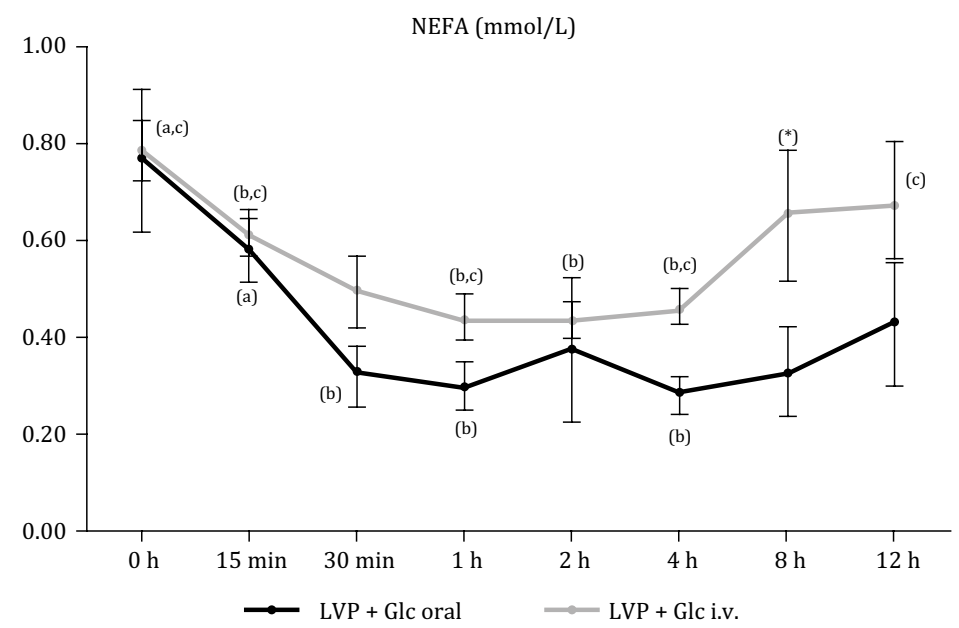

LVP + Glc oral: lysine-vasopressin + oral glucose; LVP + Glc i.v.: lysine-vasopressin + commercial glucose solution i.v. Different letters indicate statistical difference between sampling time.

Asterisk $\left({ }^{*}\right)$ indicate statistical difference between treatments $(\mathrm{P}<0.05)$

Figure 5 - Evolution of non-esterified fatty acids (NEFA) at different sampling times, corresponding to $12 \mathrm{~h}$ after the administration of treatment.

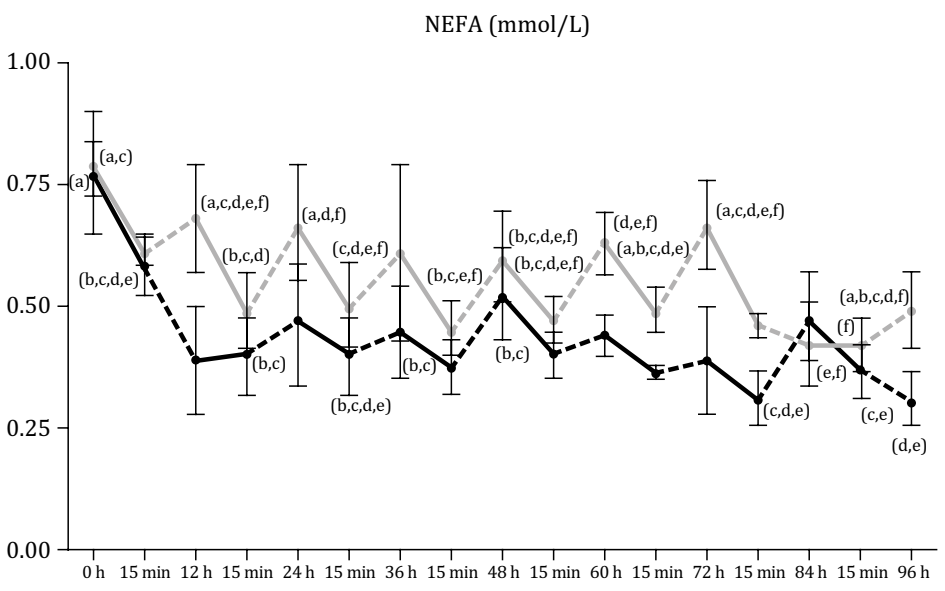

LVP + Glc oral

$\simeq$ LVP + Glc i.v

LVP + Glc oral: lysine-vasopressin + oral glucose; LVP + Glc i.v.: lysine-vasopressin + commercial glucose solution i.v. Different letters indicate statistical difference between sampling time $(\mathrm{P}<0.05)$.

Figure 6 - Evolution of non-esterified fatty acids (NEFA) in two treatments and at different sampling times during the whole trial.

Generally, the values remained high in the following $8 \mathrm{~h}$, being similar to or slightly higher than the basal ones after $12 \mathrm{~h}$, even when considering that the ewes continued fasting, with glucose as their only source of energy (El-Hamamsy et al., 1990).

The treatment of ewes with i.v. glucose resulted in unstable blood glucose levels, with a sawtooth variation, causing rapid increases followed by significant decreases and reaching the maximum values between 15 and $30 \mathrm{~min}$ post-administration (with values up to $22.99 \mathrm{mmol} / \mathrm{L}$ ) and the presence of glycosuria in all ewes, these results coinciding with those obtained by other authors (Fox, 1971; Scholz and Rehage, 1987; El-Hamamsy et al., 1990). In addition, Fox (1971) established that approximately $80 \%$ of the dose is excreted in the urine after i.v. infusion of a glucosaline solution.

Regardless of the treatment administered, all ewes showed a marked increase in blood glucose, which was initially more marked after i.v. glucose infusion (Prasad and Kaul, 1981), but also the decrease 


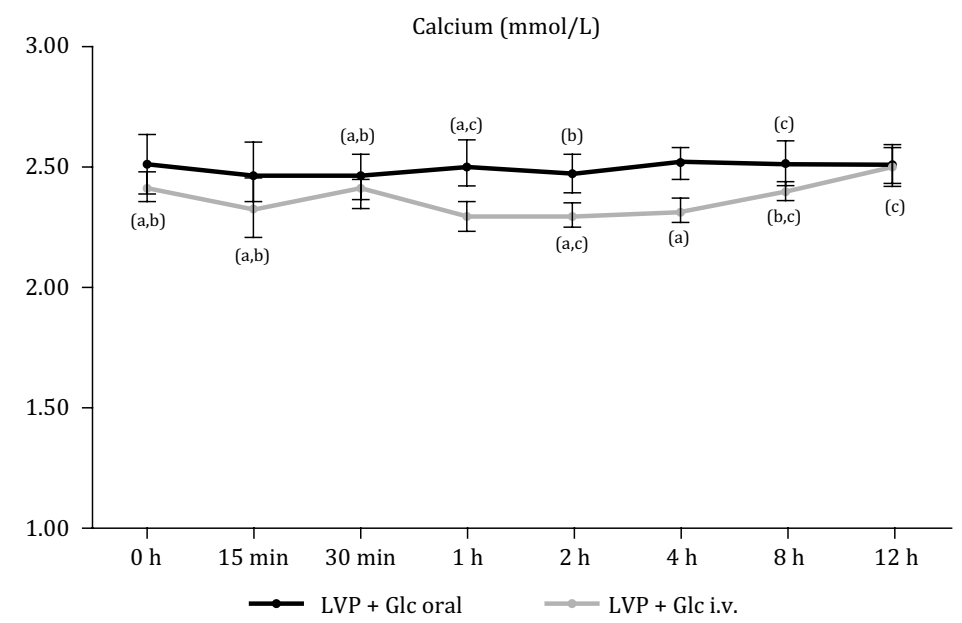

LVP + Glc oral: lysine-vasopressin + oral glucose; LVP + Glc i.v.: lysine-vasopressin + commercial glucose solution i.v. Different letters indicate statistical difference between sampling time $(\mathrm{P}<0.05)$.

Figure 7 - Evolution of calcaemia at different sampling times, corresponding to $12 \mathrm{~h}$ after the administration of treatment.

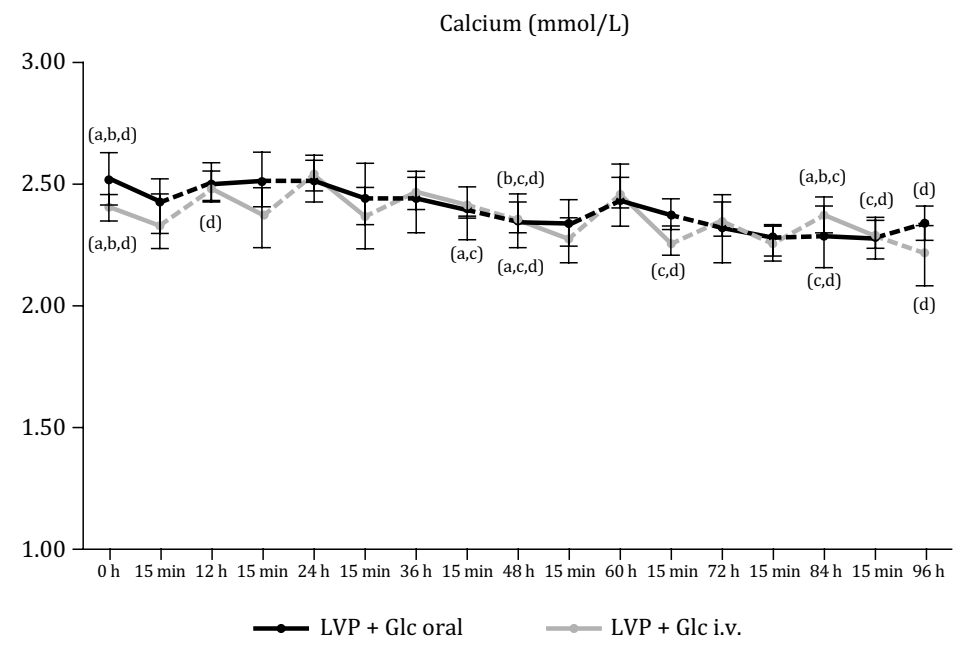

LVP + Glc oral: lysine-vasopressin + oral glucose; LVP + Glc i.v.: lysine-vasopressin + commercial glucose solution i.v. Different letters indicate statistical difference between sampling time $(\mathrm{P}<0.05)$.

Figure 8 - Evolution of calcaemia in two treatments and at different sampling times throughout the trial.

occurs more rapidly than in the ewes treated with oral glucose after medication with LVP. All this coincides with Rehage (1986), in his study on the treatment of bovine ketosis.

Due to fluctuations in blood glucose, Russel (1985) recommended studying NEFA and $\beta$-hydroxybutyrate to determine the metabolic status of an animal and, therefore, a herd, as they are less affected by handling and sampling. Normally, blood ketone levels vary in the opposite direction to glycaemia. This increase in ketonemia is caused by fasting (with a reduction in oxaloacetate), which, together with increased secretion of glucagon and epinephrine, will stimulate lipolysis and glycogenesis and high lipomobilization. Hyperketonaemia is aggravated by the lower use of ketone bodies in peripheral tissues as it cannot be burned or eliminated (Radostits et al., 2006; Sargison, 2007).

The main ketone body found in the blood of pregnant ewes is $\beta O H B$. Its concentration can be used for definitive diagnosis of the disease, as well as to detect animals at risk of developing pregnancy toxaemia. $\beta$-hydroxybutyrate concentration is measured in the blood of animals, with the threshold value used to identify animals at risk of developing the disease as $1.1 \mathrm{mmol} / \mathrm{L}$ (Russel, 1985; Sargison et al., 1994; Sargison, 2007; Braun et al., 2010; Brozos et al., 2011; Barbagianni et al., 2015). Values between 0.86 to $1.6 \mathrm{mmol} / \mathrm{L}$ have been found in sheep and goats as having mild or subclinical pregnancy toxaemia 
(Ramin et al., 2005; Bani Ismail et al., 2008), although most researchers consider $3.0 \mathrm{mmol} / \mathrm{L}$ of serum BOHB as the minimum value for diagnosing clinical OPT (Scott and Woodman, 1993; Sargison et al., 1994; Scott, 1995; Andrews, 1997; Rook, 2000; Harmeyer and Schlumbohm, 2006; Cal-Pereyra et al., 2012; Cal-Pereyra et al., 2015a). Cal-Pereyra et al. (2015a) indicated that with blood glucose values of $1.59 \mathrm{mmol} / \mathrm{L}$ and/or $\beta O H B$ in blood of $2.26 \mathrm{mmol} / \mathrm{L}$, the corresponding therapeutic measures should be established, regardless of whether the disease is subclinical or not.

Some animals showed $\beta O H B$ values between 0.37 and $1.15 \mathrm{mmol} / \mathrm{L}$, higher than those considered physiological, as possibly being a consequence of the fasting period they had been subjected to. Egan et al. (1973) recorded an increase in $\beta O H B$ values, which varied from $0.32 \mathrm{mmol} / \mathrm{L}$ in healthy sheep to $0.35 \mathrm{mmol} / \mathrm{L}$ in those subjected to a prolonged fast in the three weeks prior to calving trying to induce toxaemia, increasing to $2.68 \mathrm{mmol} / \mathrm{L}$ when the sheep developed the disease.

In our trial, ketone bodies only showed clearly elevated values in two ewes, both in blood and urine, and practically disappeared after the glucose therapy, which coincides with other previous studies (Scholz and Rehage, 1987; El-Hamamsy et al., 1990).

We verified that administration of LVP and oral glucose causes $\beta O H B$ to reach the lowest values $30 \mathrm{~min}$ post treatment, already being significant after $15 \mathrm{~min}$. Besides, in the group treated with i.v. glucose, the lowest $\beta O H B$ values were obtained between $30 \mathrm{~min}$ and $1 \mathrm{~h}$ after treatment, reaching values close to the initial ones between 4-8 $\mathrm{h}$ after treatment, and being even higher than the initial ones in some cases. With a similar therapy, based on i.v. glucose in the morning and oral glycerol in the afternoon, El-Hamamsy et al. (1990) found no decrease in blood levels of ketone bodies in diseased ewes.

Under conditions of insufficient energy supply, alimentary ketogenesis decreases and the rate of hepatic ketogenesis from NEFA increases disproportionately (Albay et al., 2014). The liver now becomes the main and eventually almost the sole ketogenic organ. Such metabolic changes are associated with marked increases in the mobilization rate of the long-chain fatty acids of adipose tissues and a marked rise in circulating concentrations of NEFA and ketones. During hyperketonaemia, ketone bodies are readily oxidised, serving as fuel for energy production (Albay et al., 2014; Cal-Pereyra et al., 2015a).

According to Rook (2000), if the blood $\beta O H B$ concentration reaches $0.7 \mathrm{mmol} / \mathrm{L}$, ketonuria is evident. In all the sheep of the experiment, we checked the presence of ketonuria before treatment, which decreased in the first hour post-treatment. Given that, according to East (1983), ketonuria can be detected before ketonemia, which is a significant circumstance to consider in the diagnosis of subclinical ketosis (Rook, 2000; Cal-Pereyra et al., 2015a).

The transient apnoea method to collect urine and measure the ketone bodies using test strips is much simpler and less laborious than bladder catheterization, as it does not cause stress to the sheep and, besides, neither blood nor urine characteristics change (Benech et al., 2015).

Enzymes (such as AST, ALT, and GGT) were maintained at all times at similar values to those indicated in references (Ortolani and Benesi, 1989; Kaneko et al., 2008). Thus, we could observe a slight increase in sheep treated with oral glucose, while they remained constant in sheep treated intravenously. When checking the liver function, Scholz (1988) also found that the administration of LVP together with glucose solutions and with a gluco-precursor, such as sodium propionate, does not cause modification of AST, GGT, or GLDH during the experiment. We observed no changes in urea or blood creatinine as a result of the respective treatments.

Both treatments caused a slight decrease in calcaemia, with statistical significance, which could be attributed to the intake of calcium at the muscular level, perhaps due to the handling of the sheep to administer the therapy and even due to the effect of LVP on the smooth muscle fibre, which increased again 30 min post-treatment. In clinical ovine toxaemia, a decrease in calcaemia has been observed (Van Saun, 2000; Schlumbohm and Harmeyer, 2003; Sargison, 2007; Jyothi et al., 2014), which can be attributed to anorexia and metabolic acidosis (Van Saun, 2000) or perhaps associated with poor hydroxylation of vitamin D in ewes with severe hepatic fatty damage (Sargison, 2007). According to 
Schlumbohm and Harmeyer (2003), the induction of hypocalcaemia produces a decrease in blood glucose; therefore, although hypocalcaemia does not promote in itself the onset of OPT, it does facilitate the development of this disease when present in combination with acetonaemia.

The mild adverse reactions found had already been pointed out by González-Montaña et al. (2014) in ewes treated with i.v. LVP and are justified by the effects of vasopressin on vascular and gastrointestinal smooth muscle and by alterations in the vagal and sympathetic tone (Flórez, 2003; Jackson, 2003; Plumb, 2010). However, none of the references consulted indicates the presence of these effects, even when the LVP was administered to sheep affected with pregnancy toxaemia (El-Hamamsy et al., 1990) or in goats (Mikhail et al., 1988), and even with higher doses from 0.1 to $0.5 \mathrm{IU} / \mathrm{kg}$ BW (Brugère and Combrisson, 1990; El-Hamamsy et al., 1990).

Although in the experiment we opted for the use of a nasogastric catheter introduced in the initial stretch of oesophagus to avoid receptors located in the mouth and pharynx being stimulated by the tested solutions (Ørskov and Benzie, 1969; Ørskov, 1972; De Vuyst, 1975; Van Weeren-Keverling Buisman et al., 1990), in clinical practice, the glucose solution could be administered by means of a bottle applied directly in the mouth of the sheep, and in our opinion, the results would be similar.

Unfortunately, in OPT, the relatively low economic value of ewes with individual character and the doubtful response to treatment must be considered in the experimental therapeutic protocols. So much so that according to Lima et al. (2016), a good strategy to minimize economic losses caused by this disease is to focus on the survival rates of the offspring instead of the females. Therefore, the proposed therapeutic trial should be considered as an alternative to conventional intravenous glucose therapy, as a base experience to continue investigating this metabolic disorder and extrapolate the knowledge acquired to other field studies related to ovine pregnancy toxaemia.

\section{Conclusions}

The administration of i.v. LVP at a dose of $0.08 \mathrm{IU} / \mathrm{kg}$ BW in sheep hardly causes any worrying signs in the animals, and they disappear quickly. In sheep treated with oral glucose after medication with LVP, a marked increase in blood glucose is observed, which remains at acceptable values for at least $8 \mathrm{~h}$ post-treatment. On the other hand, sheep treated with $50 \%$ glycated serum show a significant increase in blood glucose, which, being excreted in urine, causes a decrease in values $4 \mathrm{~h}$ after treatment, being lower than in the previous therapeutic protocol (LVP + oral glucose).

\section{Conflict of Interest}

The authors declare no conflict of interest.

\section{Author Contributions}

Conceptualization: M.J. Martín-Alonso, F. Escalera-Valente, L.G. Cal-Pereyra and J.R. González-Montaña. Data curation: F. Escalera-Valente and J.R. González-Montaña. Formal analysis: F. Escalera-Valente and J.R. González-Montaña. Funding acquisition: J.R. González-Montaña. Investigation: M.J. Martín-Alonso, F. Escalera-Valente, L.G. Cal-Pereyra, A. Benech, M.P. Alonso and J.R. González-Montaña. Methodology: M.J. Martín-Alonso, L.G. Cal-Pereyra, A. Benech, M.P. Alonso and J.R. González-Montaña. Project administration: J.R. González-Montaña. Software: F. Escalera-Valente. Writing-original draft: M.J. MartínAlonso and J.R. González-Montaña. Writing-review \& editing: M.J. Martín-Alonso, F. Escalera-Valente, L.G. Cal-Pereyra, A. Benech, M.P. Alonso and J.R. González-Montaña.

\section{Acknowledgments}

We want to express our thanks to Anna Krutter Abilla and Ana Sánchez for the linguistic revision of this manuscript. 


\section{References}

Al-Mujalli, A. A. M. 2008. Incidence and clinical study ovine pregnancy toxemia in Al-Hassa Region, Saudi Arabia. Journal of Animal and Veterinary Advances 7:210-212.

Albay, M. K.; Karakurum, M. C.; Sahinduran, S.; Sezer, K.; Yildiz, R. and Buyukoglu, T. 2014. Selected serum biochemical parameters and acute phase protein levels in a herd of Saanen goats showing signs of pregnancy toxaemia. Veterinární Medicina (Praha) 59:336-342. https://doi.org/10.17221/7620-VETMED

Andrews, A. 1997. Pregnancy toxaemia in the ewe. In Practice 19:306-312. https://doi.org/10.1136/inpract.19.6.306

Andrews, A. H.; Holland-Howes, V. E. and Wilkinson, J. I. D. 1997. Naturally occurring pregnancy toxaemia in the ewe and treatment with recombinant bovine somatotropin. Small Ruminant Research 23:191-197. https://doi.org/10.1016/ S0921-4488(96)00912-1

Bani Ismail, Z. A.; Al-Majali, A. M.; Amireh, F. and Al-Rawashdeh, O. F. 2008. Metabolic profiles in goat does in late pregnancy with and without subclinical pregnancy toxemia. Veterinary Clinical Pathology 37:434-437. https://doi.org/10.1111/ j.1939-165X.2008.00076.x

Barbagianni, M. S.; Giannenas, E.; Papadopoulos, E.; Petridis, I. G.; Spanos, S. A.; Gouletsou, P. G.; Valasi, I. and Fthenakis, G. C. 2015. Pregnancy toxaemia in ewes: Development of an experimental model and potential interactions with gastrointestinal nematode infections. Small Ruminant Research 133:102-107. https://doi.org/10.1016/j.smallrumres.2015.09.008

Benech, A.; Cal-Pereyra, L.; Da Silva, S.; Acosta-Dibarrat, J. and González-Montaña, J. R. 2015. Transient apnoea in sheep: an alternative method for serial urine sample collection. Veterinarski Arhiv 85:293-307.

BOE. 2013. Real Decreto 53/2013, de 1 de febrero, por el que se establecen las normas básicas aplicables para la protección de los animales utilizados en experimentación y otros fines científicos, incluyendo la docencia. Boletín Oficial del Estado n.34, de 8 de febrero de 2013, p.11370-11420.

Bonino, J.; Sienra, R. and Sorondo, L. 1987. Enfermedades causadas por trastornos metabólicos: toxemia de la preñez. p.239-265. In: Enfermedad de los lanares. Bonino, J.; Durán del Campo, A. and Mari, J., eds. Vol. 2. Hemisferio Sur, Montevideo, Uruguay.

Braun, J. P.; Trumel, C. and Bézille, P. 2010. Clinical biochemistry in sheep: A selected review. Small Ruminant Research 92:10-18. https://doi.org/10.1016/j.smallrumres.2010.04.002

Brozos, C.; Mavrogianni, V. S. and Fthenakis, G. C. 2011. Treatment and control of peri-parturient metabolic diseases: Pregnancy toxemia, hypocalcemia, hypomagnesemia. Veterinary Clinics of North America. Food Animal Practice 27:105-113. https://doi.org/10.1016/j.cvfa.2010.10.004

Brugère, H. and Combrisson, H. 1990. Effets de la vasopressine sur le profil moteur du réticulo-rumen chez le mouton. Reproduction Nutrition Development 30:217s-218s. https://doi.org/10.1051/rnd:19900843

Cal-Pereyra, L.; Acosta-Dibarrat, J.; Benech, A.; Da Silva, S.; Martin, A. and Gonzalez-Montaña, J. R. 2012. Toxemia de la gestación en ovejas. Revisión. Ewe pregnancy toxemia. Review. Revista Mexicana de Ciencias Pecuarias 3:247-264.

Cal-Pereyra, L.; Benech, A.; González-Montaña, J. R.; Acosta-Dibarrat, J.; Da Silva, S. and Martín, A. 2015a. Changes in the metabolic profile of pregnant ewes to an acute feed restriction in late gestation. New Zealand Veterinary Journal 63:141-146. https://doi.org/10.1080/00480169.2014.971083

Cal-Pereyra, L.; González-Montaña, J. R.; Benech, A.; Acosta-Dibarrat, J.; Martín, M. J.; Perini, S.; Abreu, M. C.; Da Silva, S. and Rodriguez, P. 2015b. Evaluation of three therapeutic alternatives for the early treatment of ovine pregnancy toxaemia. Irish Veterinary Journal 68:25. https://doi.org/10.1186/s13620-015-0053-2

De Vuyst, A. 1975. El reflejo de la gotera esofágica. Zootecnia 24:241-242.

Dzadzovski, I.; Celeska, I.; Ulchar, I.; Janevski, A. and Kirovski, D. 2015. Influence of the season on the metabolic profile in Chios sheep. Macedonian Veterinary Review 38:183-188. https://doi.org/10.14432/j.macvetrev.2015.06.048

East, N. E. 1983. Pregnancy toxemia, abortions, and periparturient diseases. Veterinary Clinics of North America. Large Animal Practice 5:601-618

Egan, D. A.; Cuill T. O. and Murrin M. P. 1973. Experimental pregnancy toxaemia of ewes. Irish Veterinary Journal 27:111-115

El-Hamamsy, H. T.; El-Neweehy, T. K.; Abdou, O. M. and Kubesy, A. A. 1990. Clinical significance of oesophageal groove vasopressin induced-closure. II. A new concept in the oral glucose treatment of pregnancy toxaemia in ewes. Veterinary Medical Journal Giza 38:373-384.

European Union. 2010. Directive 2010/63/EU of the European parliament and of the council of 22 September 2010 on the protection of animals used for scientific purposes. Official Journal of the European Union, 20.10.2010, L 276/33-79.

Flórez, J. 2003. Hormonas neurohipofisarias. Fármacos antidiuréticos. Farmacología uterina. p.671-683. In: Farmacología humana. 4 ed. Florez, J.; Armijo, J. A. and Mediavilla, A., eds. Elsevier-Masson, Barcelona, Spain. 
Fox, F. H. 1971. Clinical diagnosis and treatment of ketosis. Journal of Dairy Science 54:974-978. https://doi.org/10.3168/ jds.S0022-0302(71)85953-2

González-Montaña, J. R.; Martín, M. J.; Benech, A.; Alonso, M. E.; Alonso, A. J. and Cal-Pereyra, L. G. 2014. Handling the gastric groove closure in adult sheep using lysine-vasopressin. Small Ruminant Research 121:418-424. https://doi.org/10.1016/j.smallrumres.2014.07.025

Harmeyer, J. and Schlumbohm, C. 2006. Pregnancy impairs ketone body disposal in late gestating ewes: Implications for onset of pregnancy toxaemia. Research in Veterinary Science 81:254-264. https://doi.org/10.1016/j.rvsc.2005.10.010

Hippen, A. R.; DeFrain, J. M. and Linke, P. L. 2008. Glycerol and other energy sources for metabolism and production of transition dairy cows. p.1-17. In: Florida Ruminant Nutrition Symposium. Best Western Gateway Grand. Gainesville, FL, USA.

Jackson, E. K. 2003. Vasopresina y otros fármacos que afectan la conservación renal del agua. p.767-784. In: Las bases farmacológicas de la terapéutica. Goodman, L. S. and Gilman, A. G., eds. McGraw-Hill-Education, Mexico, DF.

Jyothi, K.; Sudhakara Reddya, B.; Pridhvidhar Reddy, Y. V.; Rao K. P.; Sivajothi, S. and Ganesan, A. 2014. Pregnancy toxemia associated with dystocia in a Nellore Brown Ewe. Advances in Applied Science Research 5:325-327.

Kaneko, J. J.; Harvey, J. W. and Bruss, M. L. 2008. Clinical biochemistry of domestic animals. 6th ed. Elsevier, Academic Press, San Diego, USA.

Lacetera, N.; Bernabucci, U.; Ronchi, B. and Nardone, A. 2001. Effects of subclinical pregnancy toxemia on immune responses in sheep. American Journal of Veterinary Research 62:1020-1024. https://doi.org/10.2460/ajvr.2001.62.1020

Lima, M. S.; Silveira, J. M.; Carolino, N.; Lamas, L. P.; Pascoal, R. A. and Hjerpe, C. A. 2016. Usefulness of clinical observations and blood chemistry values for predicting clinical outcomes in dairy goats with pregnancy toxaemia. Irish Veterinary Journal 69:16. https://doi.org/10.1186/s13620-016-0075-4

Mahmoud, S. and Azab, M. 2014. Regulation of glucose level during late pregnancy and onset of lactation in Egyptian female Baladi goats. Small Ruminant Research 121:320-324. https://doi.org/10.1016/j.smallrumres.2014.06.009

Mikhail, M.; Brugère, H.; Le Bars, H. and Colvin, H. W. Jr, 1988. Stimulated esophageal groove closure in adult goats. American Journal of Veterinary Research 49:1713-1715.

Mir, A. Q. and Malik, H. U. 2003. Oral glucose therapy-a new approach in the treatment of bovine ketosis. Indian Journal of Veterinary Medicine 23:16-18.

Ortolani, E. L. and Benesi, F. J. 1989. Ocorrência de toxemia da prenhez em cabras (Capra hircus, L) e ovelhas (Ovis aries, L) criadas no Estado de São Paulo, Brasil. Revista da Faculdade de Medicina Veterinária e Zootecnia da Universidade de São Paulo 26:229-234. https://doi.org/10.11606/issn.2318-3659.v26i2p229-234

Ørskov, E. R. 1972. Reflex closure of the oesophageal groove and its potential application in ruminant nutrition. South African Journal of Animal Science 2:169-176.

Ørskov, E. R. and Benzie, D. 1969. Studies on the oesophageal groove reflex in sheep and on the potential use of the groove to prevent the fermentation of food in the rumen. British Journal of Nutrition 23:415-420. https://doi. org/10.1079/BJN19690048

Plumb, D. C. 2010. Manual de farmacología veterinária. 6 ed. Inter-Médica, Buenos Aires, Argentina.

Prasad, M. C. and Kaul, P. L. 1981. Glucose tolerance test in goats. Zentralblatt für Veterinärmedizin. Reihe A 28:732-736. https://doi.org/10.1111/j.1439-0442.1981.tb01244.x

Radostits, O. M.; Gay, C. C.; Hinchcliff, K. W. and Constable, P. D. 2006. Veterinary medicine. A textbook of the diseases of cattle, horses, sheep, pigs and goats. 10th ed. Saunders, Elsevier, New York, USA.

Ramin, A. G.; Asri, S. and Majdani, R. 2005. Correlations among serum glucose, beta-hydroxybutyrate and urea concentrations in non-pregnant ewes. Small Ruminant Research 57:265-269. https://doi.org/10.1016/j. smallrumres.2004.08.002

Rehage, J. 1986. Untersuchungen zur Wirksamkeit oraler Glucosegaben nach Auslosung der Magenrinnenkontraktion in der Ketose-Therapie von Milchkuhen. Thesis. Faculty of Veterinary Medicine, Hannover, Germany.

Rook, J. S. 2000. Pregnancy toxemia of ewes, does, and beef cows. Veterinary Clinics of North America: Food Animal Practice 16:293-317. https://doi.org/10.1016/S0749-0720(15)30107-9

Russel, A. 1984. Body condition scoring of sheep. In Practice 6:91-93. https://doi.org/10.1136/inpract.6.3.91

Russel, A. 1985. Nutrition of the pregnant ewe. In Practice 7:23-28. https://doi.org/10.1136/inpract.7.1.23

Sargison, N. D. 2007. Pregnancy toxaemia. p.359-363. In: Diseases of sheep. 4th ed. Aitken, I. D., ed. Blackwell Publishing Professional, Ames, USA. https://doi.org/10.1002/9780470753316.ch52

Sargison, N. D.; Scott, P. R.; Penny, C. D.; Pirie, R. S. and Kelly, J. M. 1994. Plasma enzymes and metabolites as potential prognostic indices of ovine pregnancy toxaemia - A preliminary study. British Veterinary Journal 150:271-277. https://doi.org/10.1016/S0007-1935(05)80007-7

R. Bras. Zootec., 48:e20180290, 2019 
Schlumbohm, C. and Harmeyer, J. 2003. Hypocalcemia reduces endogenous glucose production in hyperketonemic sheep. Journal of Dairy Science 86:1953-1962. https://doi.org/10.3168/jds.S0022-0302(03)73783-7

Scholz, H. 1988. Utilization of the gastric groove contraction in adult cattle - A therapeutical alternative for the practitioner? The Bovine Practitioner 23:148-152.

Scholz, H. and Rehage, J. 1987. Untersuchungen zur Nutzung der Schlundrinnenkontraktion in der Behandlung interner Erkrankungen des erwachsenen Rindes. 4. Behandlung primarer Ketosen. Tierärztliche Umschau 42:280-287.

Scott, P. 1995. Differential diagnosis of common metabolic disorders of sheep. In Practice 17:266-269. https://doi. org/10.1136/inpract.17.6.266

Scott, P. R. and Woodman, M. P. 1993. An outbreak of pregnancy toxaemia in a flock of Scottish blackface sheep. Veterinary Record 133:597-598.

Tsiamitas, C. and Brikas, P. 1981. Forestomach motility in adult sheep when reticular groove closure is provoked by copper-sulfate solution. Annales de Recherches Veterinaires 12:117-121.

Van Saun, R. J. 2000. Pregnancy toxemia in a flock of sheep. Journal of the American Veterinary Medical Association 217:1536-1539. https://doi.org/10.2460/javma.2000.217.1536

Van Weeren-Keverling Buisman, A.; Kuiper, R.; Wensing, T. and Breukink, H. J. 1990. The effect of vasopressin on the closure of the reticular groove in the veal calf. Journal of Animal Physiology and Animal Nutrition 64:240-249. https://doi.org/10.1111/j.1439-0396.1990.tb00229.x 